\title{
Empirical analysis of health tourism \\ - Băile Herculane, WHERE TO? -
}

\author{
ALUCULESEI Alina-Cerasela ${ }^{1}$, NISTOREANU Puiu ${ }^{1}$
}

\begin{abstract}
Tourism is an activity practiced in our times at a large scale, with more and more people wanting to be part of this phenomenon, aware of its benefits: cultural, emotional and even health benefits. Spa tourism has a long tradition in Europe: the curative properties of water were highly valued by the Greeks and Romans, who turned the habit of bathing into a social occasion.

This form of tourism is no stranger to Romania, being practiced here since 2000 years ago, the most important evidences being the Roman built resorts such as Băile Herculane. Spa tourism is of significant importance for employee recovery after occupational stress, helps with recovering from injuries, provides a life extension and improves specific ailments associated with ageing.

This paper attempts to foray into health tourism over time - from the earliest records of the use of curative thermal waters in Europe until present, suggesting ways that we believe are beneficial for future research. The second part of the paper focuses on Băile Herculane, with an analysis of the resort tourism indicators, its present condition and possible improvements.
\end{abstract}

${ }^{1}$ Academy of Economic Studies, Bucharest

Keywords: Balneology, Băile Herculane, history of spa tourism, spa tourism, social tourism

\section{Introduction}

In a modern world increasingly characterized by technology, people have become increasingly eager to know and understand the origin of their evolution. Whether its architecture, customs or relaxation methods, tourism remains the easiest method to create connections and enrich oneself spiritually and culturally.

A complex phenomenon at the intersection of the social, cultural and economic domains, tourism has many implications "on the economy, the natural and human environment, on the population and on the destination in itself" (http://media.unwto.org/en/content/understa nding -tourism-basic-glossary). Currently, the volume of activities related to this sector exceeded exports of fuel, food and automobile production, being the main source of income in developed countries (http://www2.unwto.org/content/whytourism).
Willingness to travel arose among people for thousands of years, whether for recreational, cultural or religious purposes, in areas such as ancient Egypt, ancient Greece (Towner, 1995), the Babylonian Empire, India, (http: //ro.scribd com / doc / 150834367 / history tourism), where there was the habit of traveling to see religious buildings, the pyramids, the Olympics or to resolve various issues regarding the welfare of the empire. This habit perpetuated over time and in sixth century wealthy families were sending their children on cultural tours in order to socialize and get to know new cultures. Favorite destinations were the main cities at the time: London, Paris, Madrid, Vienna and Prague, where young people attending high society circles, including the royal court (Gyr, 2010).

An important moment in the history of tourism is the discovery of the curative properties of the springs in Europe, mainly in Greece and the Roman Empire, this being the starting point of spa tourism. The Greeks 
and Romans had a culture of bathing prophylactic and also to treat some diseases, believing that healing springs are gifts from the gods (Talarovicova, Holzner, Yilmaz, Matusikova \& Sambronska, 2010). The success of the Greek baths led to spreading of the bathing habit in most of the Mediterranean area, and testimony to this remains in the current regions of Sicily, Italy, Cyprus (Fournet, 2009), Egypt (Centre Franco - Egyptien d'etude des Temples of Karnak , 2013).

Proof of this is that special attention was given to public bath buildings, "which are decorated with mosaics, sculptures and paintings, being given as much importance as theaters or coliseums. [...] Even if every building was unique, their subdivision was the same - there is a dressing room, outdoor gymnasium, cold room with swimming pool, warm room, hot room, dry room ". It should be noted that the baths had a strong social role, being used by all citizens, including the slaves (Schwein, 2014). The largest public bath of the Roman Empire was the "Diocletian bath with a built area encompassing 130,000 sq. Yards "(Comenius Project, 2012).

The use of waters for curative purposes is representative not only for Europe but also for Asia, being dated according to archaeological finds as early as the Bronze Age, over 5000 years ago. In the United States one cannot talk about spa tourism culture as in Europe, although the properties of thermal water springs were discovered and recognized by locals for centuries. In this geographical area there are three stages identified for the use of water in therapy: in the first stage, the water was used by the Indians and attributed to a sacred place; in the second stage in which the Europeans who came to America used the springs in the same fashion they were used in Europe and the third stage, the current one, in which resorts were relaxation and wellness (fitness) are combined. It is worth noting that the Indians regarded springs as sacred places to where they came in order to recover from battles, sharing them with rival tribes. A proof of the natives' appreciation of these waters is the effort to keep their existence secret from Europeans as much as possible (Lund \& Center, 2000).

The tradition of the Turkish baths is also known, these baths being an adaptation of the Roman model of public baths. "The tradition of the Turkish bath, hamman, in addition to the goals of cleaning the body and maintaining good health also has a religious purpose, related to the Muslim custom of washing (purifying) before entering the mosque" (Castiglia \& Bevilacqua, 2008). In general, the Turkish baths were owned by the state public and could be rented for a sum of money (Benaboud \& Cherif, 2013).

During the Middle Ages there was a decline in bathing, the main reasons being religion and the high number of battles that led people in Europe to seldom use water to clean their body, "sometimes letting a few years pass between two bathing" (http : //ard.bmj.com/content/61/3/273.full).

However, the therapeutic properties of the springs were not forgotten and the people living near healing waters continued using them to treat various diseases. There were also areas where bathing continued usually perpetuated by invading peoples like in the Iberian Peninsula and Andalusia - with the arrival of the Moors and in areas where Turks entered. After the seventeenth century, when King Henry IV of France inaugurated the festival of Mineral Water the use of thermal springs started gaining momentum again, and the twentieth century coincides with a new phase of this form of tourism, in which a growing number of people from different social groups have access to balneary resorts (http://termalismo.ourense.es/wpcontent/uploads/2013/01/EHTTA_european _route.pdf).

Although at first it was destined only for wealthier families who could afford to 
travel hundreds of kilometers away from home in a time when the road network was underdeveloped and unsafe, spa tourism started taking a different direction after the eighteenth century. Practiced in Germany for maintaining health and socializing, it began to expand into other countries after casinos in Germany and the Czech Republic were banned. After the Second World War, resorts were attended by former soldiers who needed rehabilitation, and later started to turn into mass tourism (Breitruck \& Nunn, 2011).

Currently, health tourism is practiced especially in Europe and countries with significant dynamics include Germany, Italy, France, Spain and to a lesser extent the Czech Republic, Slovakia, Hungary and Poland (Banabdallah \& Tomatis, 2009).

\section{Spa tourism in Romania}

Spa tourism is a form of tourism not affected by seasons because the treatment plans can be performed at any time of the year, with most of the insured citizens preferring to spend their vacations in spa resorts. Thus, in order to promote spa tourism during periods with reduced tourist traffic, programs such as "A week of recovery", "Balneary Decade", "Come to Baths", "Balneary Wellness" (Surugiu, Stanciu, Tudorache, Rădulsecu \& Dragoman, 2012) were developed by OPTBR (Patronal Organization Of Spa Tourism) which provide accommodation, treatment and meals in hotels rated at 2, 3 and 4 stars (Gheorhe, Bulin \& Nistoreanu, 2012). Encouraging this type of tourism is accelerated by the aging of the population and increase in morbidity (Erdeli, Dincã, Gheorghilaş, Surugiu, 2011).

In Romania, the images of spa tourism and social tourism overlap. This approach is due to the fact that the key decision makers in spa tourism are the National Pension House, the National Authority for Youth and Sports and the
Patronal Organization Of Spa Tourism and there are several national initiatives to stimulate this segment: the Holiday Vouchers Program and the Social Spa Tourism Program. We consider this phenomenon to be unfair because of the complexity of spa tourism, which involves both the recovery and the extension of wellness of citizens, regardless of age. Also the wellness segment supports our claim, as it is intended for those with an income above average.

The intended target segments for the discount treatment tickets are retirees and those insured by the state system. Based on a referral letter received from the family doctor and the current month's pension ticket, retirees can be treated at any of the resorts in the country, paying only $70 \%$ $80 \%$ of the monthly pension (Stanciu, 2006).

This social form of spa tourism in Romania means that most of the tourists that come to resorts - $65 \%$ - come through the National Pension House. Foreign tourists who prefer Romanian resorts have a proportion of $10 \%$, and they are brought by travel agencies specialized in the incoming segment. The favorite resorts in this case are mostly those who benefited from investments for modernization, such as Băile Felix, Sovata, Slănic Moldova, Buziaş (Rădulescu, 2013).

Besides retirees, the other insured citizens also receive rehabilitation treatment on a referral letter from the "family doctor, the specialist doctor from the hospital or local clinic". They are entitled to a maximum of two treatment sessions per year, each with an average of 10 days of treatment and 4 treatment procedures / day and if they exceed this threshold then they are forced to pay in full for the medical services they receive (http://www.casmb.ro/asigurati_servicii_me dicale_de_recuperare_medicina_fizica_si_ba lneologie.php).

Also, health tourism is is entirely free of charge for certain social categories such 
as disability pensioners, the persons persecuted for political or ethnic reasons, war veterans, disabled war veterans and war widows, disabled adults. Others who qualify for free are those who work in special conditions and environments such as research, exploration and processing of nuclear materials, those who have had workrelated injuries and people who have acquired professional diseases (http: / /www.tbrcm.ro/bilete-treatment-withoutplata.php).

Regarding the dynamics of tickets for rest and treatment granted under state social insurance, the results are shown in Fig. No. 1. - 2000-2013 period. It presents both the national situation and the situation of one of the most famous resorts in Romania, Băile Herculane.

Fig. No. 1 Dynamics of tickets for rest and treatment granted under state social insurance between 2000-2013

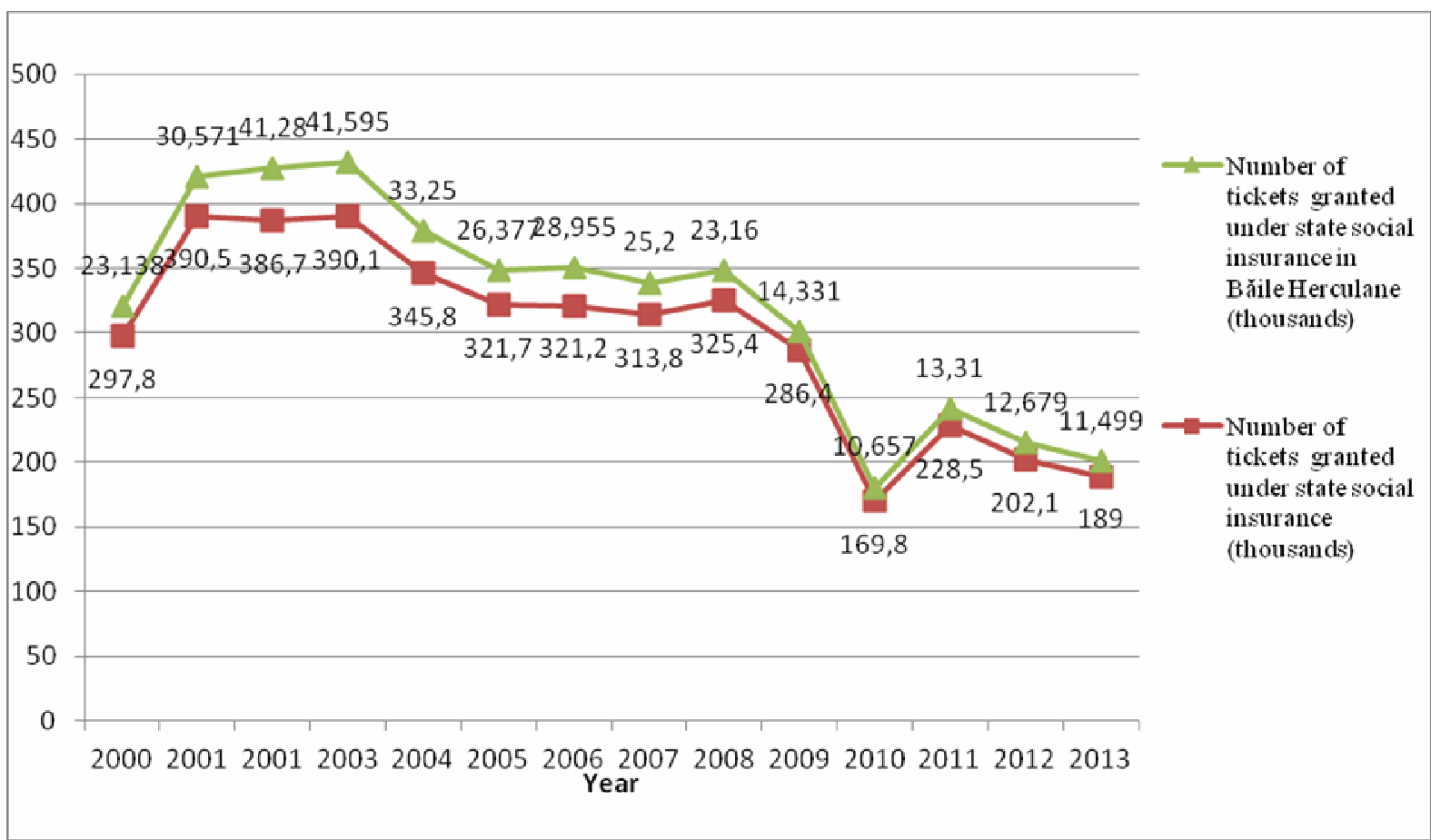

Source: Created by the authors based on information from PSA103A - Tickets for treatment and rest provided under state social insurance (www.insse.ro)

What is interesting is that the dynamics of the number of tickets in the period under review in Băile Herculane have exactly the same pattern as the situation at the national level. The year when with the highest number of tickets was 2001, with a value very close to 2003 . Then their number starts decreasing more and more, registering a minimum in 2010 - at almost half of the value from 2001. The following year registers a slight recovery, but in 2012 and 2013, the number of tickets issued decreases again.

Although the population starts following the Western European trend in terms of age average, the interest in spa resort development is low. Inclination towards spa tourism should be higher, since the annual treatment plans ensure a lower morbidity, leading to a significant reduction 
in total spending for the health budget. This aspect is obvious from the analysis of the accommodation capacity, which in 2013 is close to the bottom of the list, before the Danube Delta - Fig. No. 2.

Fig. No. 2 Accommodation capacity in Romania in 2013

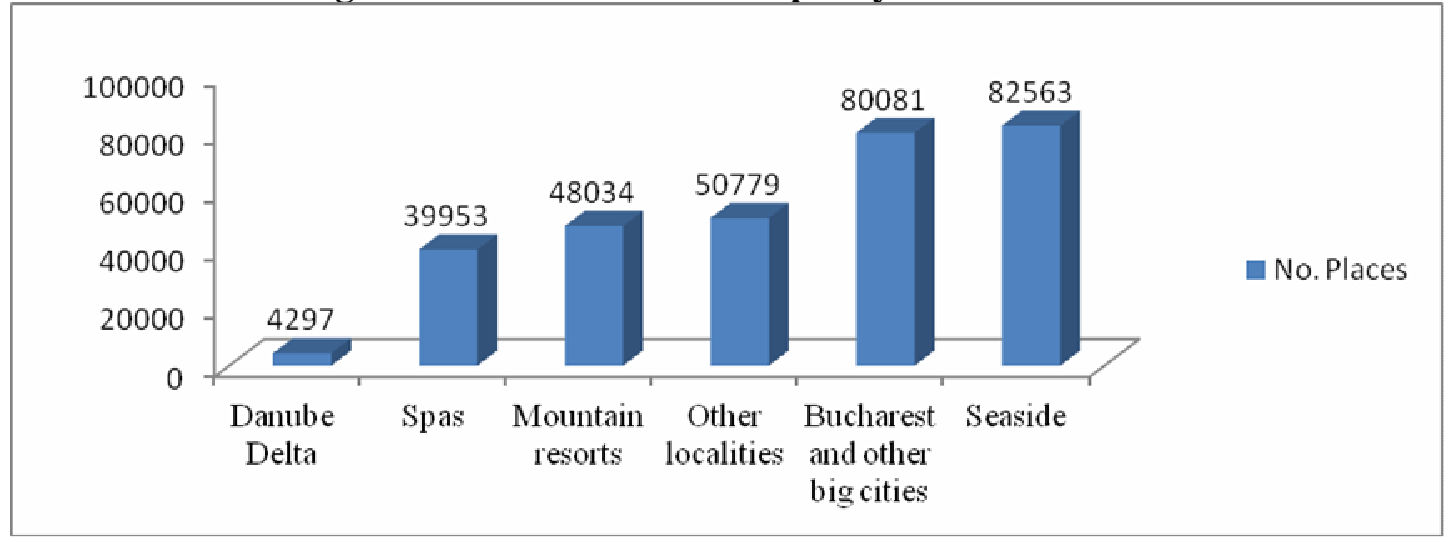

Source: Created by the authors based on statistical abstract "Romania's Tourism" 2014

The seaside recorded the highest number of accommodation places, followed by the capital city and other cities of residence, which shows the momentum gained by business tourism in our country. Mountain resorts have an accommodation capacity of about half that of the coastline and the offset to spa resorts is almost 12,000 places, three times the capacity of the Danube Delta accommodation. This can be explained by the fact that investments in tourism were not significant and most units built in recent years have been hostel-type units with fewer beds. Large hotels built during communism, with hundreds of beds per unit were closed down in some resorts due to degradation and lack of investment or maintenance.

The situation of Romanian resorts can also be deduced from the low proportion of foreign tourists who choose our country for rehabilitation treatment or wellness. They choose Romanian destinations because the prices here are much lower for the quality of medical care they require, although treatment standards are not those expected. The following table (Table No.1) presents the situation of Romanian and foreign tourist arrivals by type of accommodation.

Table No. 1 Romanian and foreign tourists arrivals in spa resorts (2013)

\begin{tabular}{l|ccccccc|} 
No. $\%$ Total & 5 stars & 4 stars & 3 stars & 2 stars & 1 star & Unclasifed \\
\hline $\begin{array}{l}\text { Romanian tourists } \\
\text { (No) }\end{array}$ & 646228 & 288 & 100591 & 226028 & 298443 & 14097 & 6781 \\
$\begin{array}{l}\text { Romanian tourists } \\
(\%)\end{array}$ & $100 \%$ & $0,04 \%$ & $15,57 \%$ & $34,98 \%$ & $46,18 \%$ & $2,18 \%$ & $1,05 \%$ \\
Foreign tourists (No) & 32308 & 36 & 11743 & 9171 & 11115 & 205 & 38 \\
Foreign tourists (\%) & $100 \%$ & $0,11 \%$ & $36,35 \%$ & $28,39 \%$ & $34,40 \%$ & $0,63 \%$ & $0,12 \%$ \\
\hline
\end{tabular}

Source: Created by the authors based on statistical abstract "Romania's Tourism" 2014 
One can notice a stronger attraction for foreign tourists towards 4 and 5 star units in contrast to the Romanians, who prefer in a proportion of the $36 \%$ the 4-star units, one reason being the comfort level they seek while on vacation. On the other hand, the highest proportion of Romanian tourists prefers the 2-star units which can be explained through the social implication of this type of tourism in Romania. The fact that retirees can go on vacation to spa resorts for treatment attracts the request for a lower comfort level, the lower price being more important to this social group.

In regards to the situation of health tourism at the European level, studies by Eurostat show that health tourism motivation is quite low among tourists. Although in countries such as Austria, France and
Germany the wellness side of health tourism is represented stronger than the treatment side, the high costs associated with the treatment plans are significant aspects and explain the low level of motivation for health tourism. In the study published by Eurostat, Eurobarometer 2014, the respondents answered to the question "What is the main reason for which going on holiday" (multiple answer) and most of them answered sun / beach. Which shows that the perfect holiday in the minds of many, is during a warm period, in a warm area or near water. Fig. No. 3 presents the comparative responses on the motivation of Europeans during 2013 and 2014.

Fig. No. 3 Motivation of European tourists for vacations (\%)

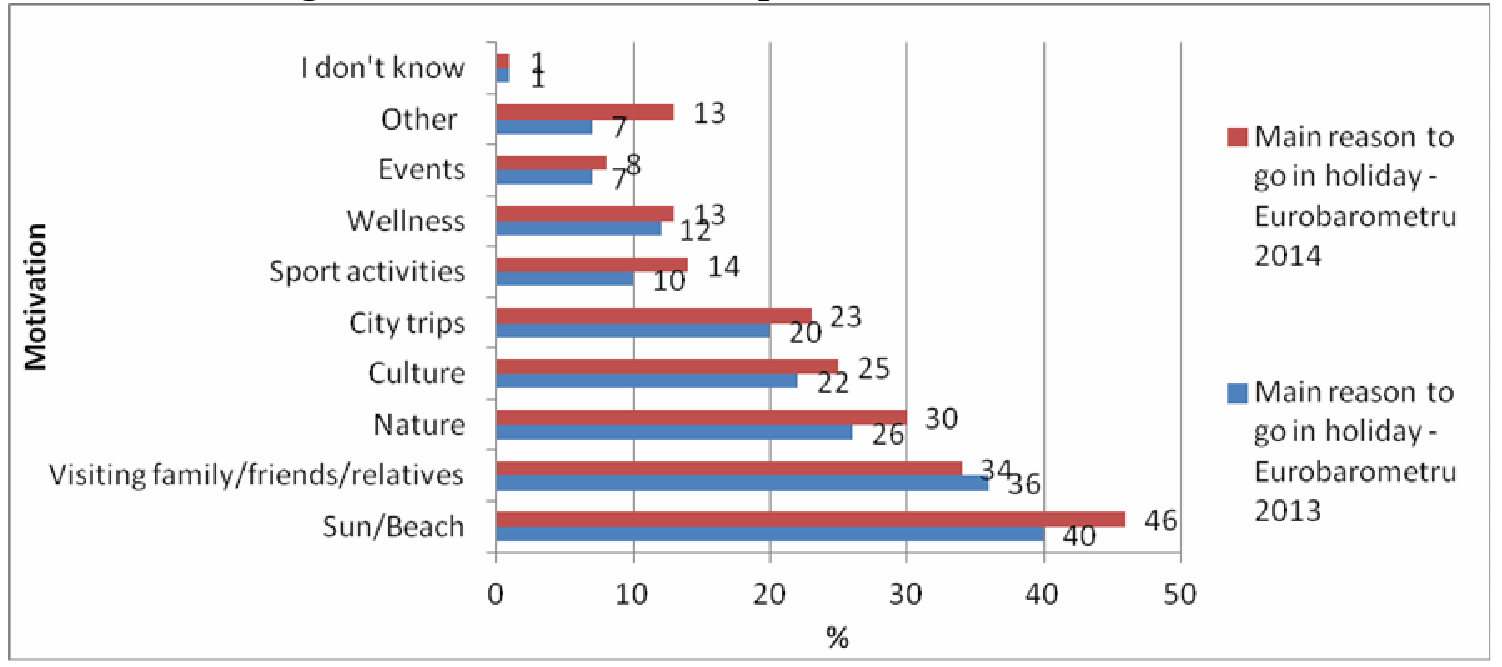

Source: Created by the authors based on data from Eurobarometer 2014 and Eurobarometer 2013

The biggest difference in the answers of respondents in 2014 compared to 2013 is the motivation for sun and beach, in the past year it increased by 6 percent over the previous year. The trend of percentage growth rates in the current year compared to 2013 is the same for all response options with the exception of visits to friends / family / relatives which experienced a two percent decrease in motivation.

\section{Băile Herculane Resort - Romanian spa tourism emblem}

It is a known fact that the spa resort Băile Herculane is the oldest in the country and it was founded by order of the Emperor Trajan and it was named after the god Hercules, whom the Romans considered to be the patron of thermal waters. The area has many legends linking sites in Cerna Valley 
to the hero Hercules, saying that on his way to the Caucasus in search of the Golden Fleece he crossed this area and after a hard fought battle with a dragon, he regained his strength after bathing in the springs of the current resort (http://lup.lub.lu.se/luur/down load function $=$ downloadFile $\&$ recordOId $=2201469 \&$ fileOId $=2,214,427$ ).

During the Roman occupation, the resort adopted from the Imperial capital the habit of coming to the baths for treatment and especially for socializing. After the departure of the Romans from Dacia, baths continued to be used by the locals, but their degradation became more pronounced, especially because of the wars during that time (Cohut \& Arpaşul, 1995). The resort has two main stages: the Roman stage and the Austro-Hungarian stage, when it gains international notoriety. The beauty of the buildings and facilities which were of the highest quality for that time have made significant figures of the time such as the Emperor Francis I, Empress Charlotte, Emperor Franz Joseph and Empress Elisabeth come to the resort and leave testimony of their appreciation (Munteanu, 2011).

The resort is indicated for the treatment of many diseases, such as "musculoskeletal diseases, degenerative rheumatic joint diseases, inflammatory diseases, joint diseases, recovery from musculoskeletal trauma, peripheral nervous system disorders, paresis, paralysis, chronic respiratory diseases, bronchitis, rhinitis, sinusitis, asthma, chronic gynecological diseases, diabetes, heavy metal poisoning, digestive diseases, eye diseases, metabolic syndrome

"(http://spas.ro/statiuni/Baile_Herculane/). It was included in the top 10 resorts by the Romanian Association of Balneology, on the eighth place. The criteria for this evaluation were availability, the existence of structures dedicated to education and scientific research, external notoriety, internal notoriety, quality of natural treatment factors, the quality of tourism services, existence of resort development strategies, the level of investment in treatment facilities, the willingness of local decision makers and investors to engage in dialogue, scientific awards attesting to the excellence level of the resort. The first two places were awarded to Techirghiol and Băile Felix resorts. Băile Herculane obtained a total of 55 points out of 100 , with the lowest score being awarded for the existence of structures dedicated to education and scientific research (http://bioclima.ro/Top.htm).

Although the decline of the Băile Herculane resort is evident and many warning signs are drawn each year unfortunately ignored by local authorities, the investments in accommodation infrastructure have risen. The number of housing units increased from year to year, climbing from a total of 11 in 1992 to 62 units in 2013. Fig. No. 4 shows the situation of tourist accommodation structures for the period between 1992-2013. 
Fig. No. 4 The situation of tourist accommodation structures for the 1992-2013 period in Băile Herculane

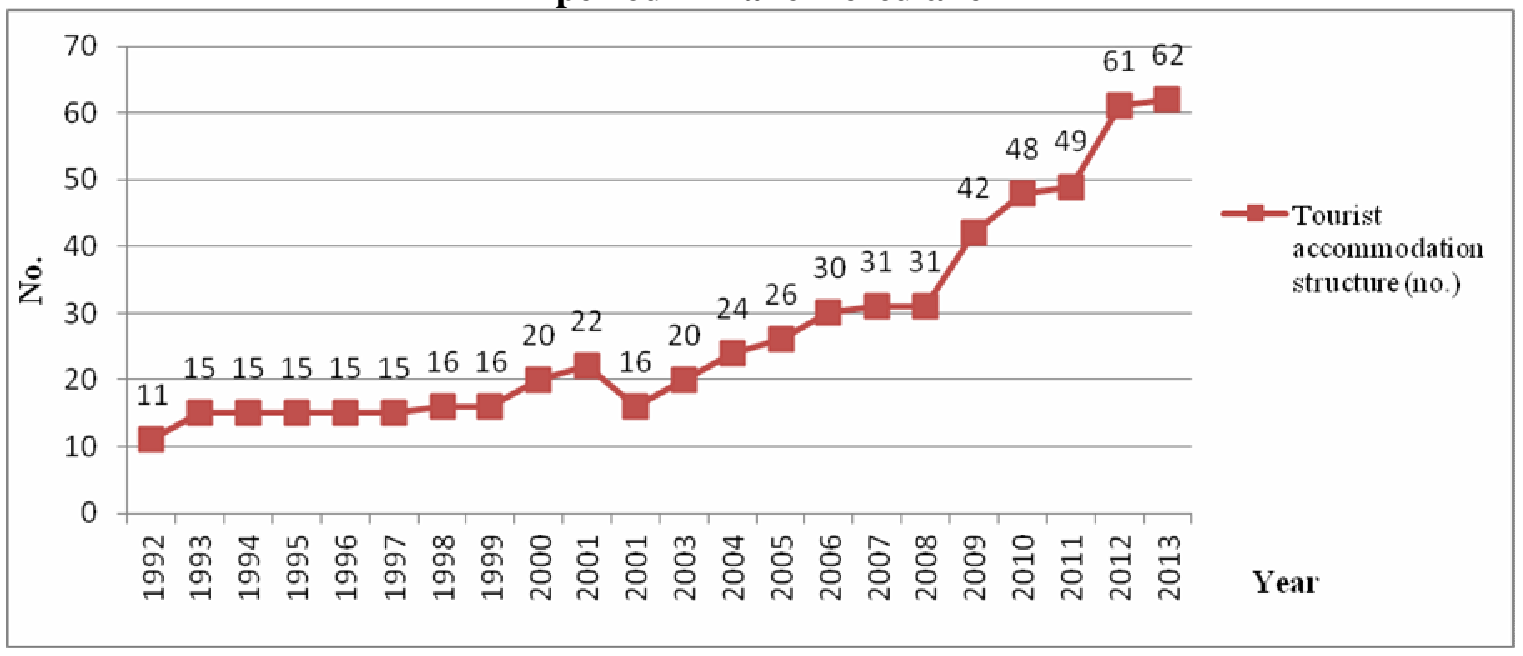

Source: Created by the authors based on information from TUR101C - tourist reception structures with the purpose of tourist accommodation according to the types of structures, counties and cities

During 1993-1997, the number of accommodation structures in the resort has remained constant - 15 units, proving that investors in tourism did not turn their attention to this area in the period described. One reason is the quite unstable economic and legal situation in the country, which induced a high level of investment risk. After 2007, when Romania joined the European Union and with the accessing of tourism programs by legal entities, the number of units increased from year to year, ranging from 31 around the time of joing the EU, to 62 in 2013.

Although investment in accommodation units increased, this did not coincide with an increase in arrivals. This can be explained by the nature of the resort. Băile Herculane is a resort where internal and external treatment plans can be performed, and it is recommended for the treatment of many diseases. However, the treatment plan should be done in treatment centers which meet sanitary and patient protection standards as well as quality requirements. Providing just a modern housing infrastructure cannot cover the medical infrastructure gap. Thus, if during the 1992 - 2001 period the number of arrivals is around 5000 (between a maximum of 5060 and a minimum of 5342), after this year the number of arrivals decreased by 1000 , with the lowest level recorded in 2011 - 4050 arrivals.

Although the resort's potential is acknowledged, the investments needed to transform it into a famous balneology center are lacking. The town hall is involved in a few projects, one of which is the rehabilitation of the Villa Elizabeth located in the resort center ( an European program worth euro 3.2 million) (http://www.administratie.ro/articol.php?i $\mathrm{d}=28814$ )

Low authorities' lack of interest towards Băile Herculane is visible throughout the resort. Buildings of unique beauty, built in the time of the AustroHungarian Empire are left in an advanced state of decay and the access inside these buildings, although banned, is easy for anyone. The exterior and the interior of the buildings are in a deplorable condition 
giving the impression of an abandoned resort, especially during periods with few tourists. The SWOT analysis, presented in Fig. No. 5 shows strengths and weaknesses of the resort and the opportunities and threats that must be taken into account for the revitalization of the village.

Figure No. 5 SWOT Analysis of Băile Herculane

\begin{tabular}{|c|c|}
\hline Strengths & Weaknesses \\
\hline $\begin{array}{l}\text { - Located in an exceptional natural } \\
\text { environment } \\
\text { - Gained notoriety; } \\
\text { - The large number of diseases treated; } \\
\text { - The capability for both domestic and } \\
\text { foreign treatment plans; } \\
\text { - } 2000 \text { years history; } \\
\text { - The presence of Roman remains; } \\
\text { - The existence of buildings with unique } \\
\text { architecture, which housed political } \\
\text { figures; } \\
\text { The ability to practice other types of } \\
\text { tourism in the area: adventure tourism } \\
\text { (rafting), culinary tourism, cultural } \\
\text { tourism, ecotourism; }\end{array}$ & $\begin{array}{l}\text { - The poor condition of buildings - those } \\
\text { with an outstanding architecture and } \\
\text { history are closed; } \\
\text { - The poor condition of roads in the } \\
\text { village; } \\
\text { - The catering is poorly developed; } \\
\text { - Inadequate maintenance of Cerna river } \\
\text { that runs through the resort; } \\
\text { - Poor absorption of European funds to } \\
\text { modernize the resort }\end{array}$ \\
\hline Opportunities & Threats \\
\hline $\begin{array}{l}\text { - Positioning of the resort in southwest - near } \\
\text { the border with Bulgaria, Serbia and } \\
\text { Hungary; } \\
\text { - Starting of the new EU Funds program for } \\
\text { 2014-2020; } \\
\text { Existence of cosmetic companies (Farmec) } \\
\text { that could create a special line of products } \\
\text { based on the Herculane waters; } \\
\text { - Increased interest of the elderly in } \\
\text { developed European countries for wellness; }\end{array}$ & $\begin{array}{l}\text { - The development of balneary resorts in } \\
\text { Hungary; } \\
\text { - The decrease in budget for Romanian } \\
\text { tourists; } \\
\text { - The low interest of local authorities to } \\
\text { develop the resort; }\end{array}$ \\
\hline
\end{tabular}

Source: Created by the authors based on field research (February-June 2014)

Although many years have passed during which things have stagnated and even rolled back, the resort can regain the image and reputation it had in the past, and it can come back on the market even with new elements. In addition to the dire need for investment in the required infrastructure, we have identified the opportunity to create a productive partnership with real economic implications for the parties involved.
The resort can collaborate with one of the pharmaceutical production companies in the country to develop a special range of products such as creams, emulsions, lotions to be sold in the local treatment centers at the reception desks of hotels and guesthouses as well as in stores. The possible implications of this measure are:

The tourists are most often interested in these products will be pleased 
they can take home a souvenir beneficial for their health;

The resort and the company involved in this partnership will create new jobs;

$>$ The income of those involved in tourism in the area (hotels, hostels, shops, treatment centers) will increase as a result of the sale of such products;

$>$ The amount collected in taxes will increase;

$>$ The resort will benefit from advertising in the places of residence of tourists who buy these products through packaging and labels made in a professional manner;

Even if the necessary investments in the resort are in the order of hundreds of millions of euro, the total of investments made by the authorities may diminish significantly by attracting European funds for tourist activities and conservation of heritage buildings. The opportunity which Romania has by owning a balneary resort such as Băile Herculane can be turned into an asset for Romanian tourism, especially since there are multiple parties to benefit from this: the owners of units and treatment centers, catering business owners, tourists, locals and even the state.

\section{Conclusions}

Spa tourism is a form of tourism that helps with recovery after accidents and after long periods of stress, with another important aspect being that it is beneficial in improving certain health conditions of the elderly. An early conclusion that can be drawn from the analysis of spa tourism in Romania is its importance for tourism activity in Romania. This form of tourism brings benefits to the economic agents involved as well as the rest of the country's population who can get treatment in these health resorts. Health recovery can be achieved at a low price in our country because of measures meant to encourage this activity and because of treatment vouchers granted by specialized state institutions.

Despite the history and experience that we have in terms of health tourism, Romania is not yet ready to become a center of attraction for Europeans interested in recovery. Among the reasons identified are the current state of the resorts and the state of tourism and health infrastructure.

Băile Herculane resort can be considered the balneology emblem in our country. Although it finds itself in an advanced state of decay, there are still solutions for its revitalization and transformation into the resort which decades ago attracted important figures of the time.

In conclusion, spa tourism is an important pillar both for the Romanian tourism system and for the improvement of health for those who come seeking treatment in the spa resorts. Its potential is very high, and from this point of view, Romania can compete with other such dedicated areas in Europe. Although there are measures to encourage and support this type of tourism, substantial investments and increased attention are required from the authorities in order for tourists to enjoy their holiday at modern standards.

\section{Acknowledgements}

Research funded by the project " MINERVA-Cooperation for elite careers in doctoral and post-doctoral research" Contract Code: HRD / 159 / 1.5 / S / 137,832, project co-financed by the European Social Fund through the Human Resources Development Operational Sectorial Program 2007-2013. 


\section{Bibliography}

1. Banabdallah, J. \& Tomatis, J., Masterplan pentru dezvoltarea turismului balnear, Detente Consultants, 2009;

2. Benaboud, M. \& Cherif, M., De AlAndalus Tetuan, Tomo, 2013;

3. Breitruck, V. \& Nunn E., Health \& medical tourism Simply synonyms?, A. Papathanassis Publisher, Springer Fachmedien Wiesbaden, 2011;

4. Cohut, I. \& Arpasi, M., Ancient Uses of Geothermal Waters the Precarpathian Area of Romania and Pannonian Basin of Hungary, World Geothermal Congress, 1995;

5. Castiglia, R. \& Bevilacqua, M., G., The Turkish Baths in Elbasan: Architecture, Geometry and Wellbeing, NEXUS NETWORK JOURNAL - VOL. 10, No. 2, 2008;

6. Erdeli, G., Dincă, A.I., Gheorghilaș, A., Surugiu, C., Romanian spa tourism: a communist paradigm in a post communist era, HUMAN GEOGRAPHIES - Journal of Studies and Research in Human Geography, Vol. 5, No.2, 2011;

7. Fournet, T., The ancient baths of southern Syria in their Near Eastern context, International FrontinusSymposium on the Technical and Cultural History of Ancient Baths, Aachen, 2009;

8. Gheorhe, G., Bulin, D. \& Nistoreanu, P., Social Tourism - an Alternative Form of Tourism in Romania, Cactus Tourism Journal Vol. 3, No. 2, 2012;

9. Gyr, U., The history of tourism, The Institute of European History, Mainz, 2010;

10. Lund, J. \& Center G., H., "TAKING THE WATERS INTRODUCTION TO BALNEOLOGY, GHC Bulletin, 2000
11. Munteanu, C., Stațiunea Băile Herculane, Balneao-Research Journal, Vol. 2, No. 3, 2011;

12. Rădulescu, N., Dezvoltarea turismului balnear in Romania. Modalitati de valorificare a potentialului national, Forumul Internațional pentru Turismul de Sănătate Târgu Mureș, 2013;

13. Schwein, M., An Incantation Bowl and Roman Bath House, 2014;

14. Stanciu, P., POLITICI DE PROMOVARE A TURISMULUI SOCIAL ROMÂNESC, Revista de turism, Vol 1, No. 2, 2006;

15. Surugiu, C., Stanciu, R., Tudorache, D., Rădulescu, A. \& Dragoman, S., PROGRAMUL DE SCHIMB ÎN TURISMUL DE SĂNĂTATE (HEALTOUR), 2012;

16. Talarovicova, V., Holzner, J., Yilmaz, Y., Matusikova, D. \& Sambronska, K., Spa Tourism Textbook, GRAFOTLAČ PREŠOV, PREŠOV;

17. Towner, J., What is tourism' $s$ history?, Tourism Management, Vol. 15, No. 5, 1995, Elsevier Science;

18. *** Centre franco-égyptien d'étude des temples de Karnak, Cahiers de Karnak, Cairo, 2013

19. ***Comenius Project Italy-SpainAustria-Portugal-Greece, Thermal springs in Europe, 2012;

20. ***European Commision, Eurobarometru 2014, Preferences of Europeans towards tourism, 2014;

21. ***European Commision, Eurobarometru 2013, Preferences of Europeans towards tourism, 2013;

22. ***Institutul Național de Statistică, Breviarului statistic "Turismul României" 2014, 2014;

23. ***http://www.administratie.ro/artico 1.php?id=28814, accessed at 25.08.2014; 
24. ***http://ard.bmj.com/content/61/3/2 73.full, accessed at 15.08.2014;

25. *** http://bioclima.ro/Top.htm, accessed at 20.08.2014;

26. ***http://www.casmb.ro/asigurati_se rvicii_medicale_de_recuperare_medi cina_fizica_si_balneologie.php, accessed at 15.08.2014;

27. ***http://lup.lub.lu.se/luur/download ? func $=$ downloadFile \& recordOId $=22$ 01469\&fileOId $=2214427$, accessed at 15.08.2014;

28. ***http://media.unwto.org/en/content lunderstanding-tourism-basicglossary, accessed at 10.08.2014;

29. ***http://ro.scribd.com/doc/1508343 67/ISTORIA-TURISMULUI,

30. $* * *$ accessed at 10.08.2014;

http://spas.ro/statiuni/Baile Herculan e/, accessed at 20.08.2014;

31. ***http://www.tbrcm.ro/biletetratament-fara-plata.php, accessed at 15.08.2014;

32. ***http://www2.unwto.org/content/w hy-tourism, accessed at 10.08.2014; 